\title{
TWO KINDS OF TRYPTAMINE RECEPTOR
}

\author{
BY \\ J. H. GADDUM AND Z. P. PICARELLI* \\ From the Department of Pharmacology, University of Edinburgh
}

(RECEIVED MARCH 6, 1957)

There are two kinds of tryptamine receptor in the guinea-pig ileum, namely the $M$ receptors which can be blocked with morphine and the $\mathrm{D}$ receptors which can be blocked with dibenzyline. Atropine, an atropine-like drug, cocaine, and methadone inhibit effects due to the $M$ receptors, even after dibenzyline, but have no additional effect after morphine. Lysergic acid diethylamide, dihydroergotamine and 5-benzyloxygramine inhibit effects due to the $\mathrm{D}$ receptors, even after morphine, but have no additional effect after dibenzyline. The $M$ receptors are probably in the nervous tissue and the $\mathrm{D}$ receptors are probably in the muscles.

The drugs which act as antagonists of 5hydroxytryptamine (5-HT) give different results when tested on different preparations. Various derivatives of ergot have been found to be very potent antagonists of 5-HT in experiments on the rat uterus or on the rabbit ear perfused with salt solutions, but the ergot derivatives were not, however, very potent antagonists of 5-HT in the case of the guinea-pig ileum (Fingl and Gaddum, 1953; Gaddum, 1953; Gaddum and Hameed, 1954; Gaddum, Hameed, Hathway, and Stephens, 1955).

In order to explain such facts, Gaddum and Hameed (1954) suggested the existence of two kinds of tryptamine receptor: one in the plain muscle of the rat uterus and the rabbit ear which was easily blocked by lysergic acid diethylamide (LSD), gramine, or dihydroergotamine, and another in the intestine, not easily blocked by such drugs.

There is evidence that 5-HT causes contraction of the guinea-pig intestine by acting through the nerves, but this is not due to an action on the nicotine receptors, since it is not suppressed by hexamethonium or by the eventual paralytic action of large doses of nicotine (Rocha e Silva, Valle and Picarelli, 1953 ; Robertson, 1953). The tryptamine receptors seem, in fact, to be different from other kinds of receptor, since large doses of 5-HT eventually abolish the effect of 5-HT itself on guinea-pig intestine without diminishing the response to histamine or substance $P$ (Gaddum, 1953) or acetylcholine or nicotine (Rocha e Silva et al., 1953).

Gaddum and Hameed (1954) found that LSD, in a concentration of $0.1 \mu \mathrm{g} . / \mathrm{ml}$., diminished the

\footnotetext{
*Present address: Laboratorios de Farmacologia e Bioquimica. Escola Paulista de Medicina, São Paulo, Brazil.
}

response of guinea-pig ileum to $5-\mathrm{HT}$ by $50 \%$, but concentrations 100 times larger had no more effect. Cambridge and Holgate (1955) made similar observations with atropine, using histamine and acetylcholine as control drugs. When the responses of guinea-pig ileum to a constant dose of agonist were plotted against the log. dose of atropine these two drugs gave simple S-shaped curves, but with 5-HT there was a plateau over the range of concentrations 0.01 to $1.0 \mu \mathrm{g}$. $/ \mathrm{ml}$. These observations could be explained on the theory that the two types of receptor postulated by Gaddum and Hameed are both present in the guinea-pig ileum and drugs may block one type of receptor without affecting the other type. The results described below confirm this theory and provide a method of studying each type of receptor separately by eliminating the effects of the other type with specific antagonists.

\section{MethodS}

Guinea-pig Ileum Preparation.-Pieces of terminal ileum were removed from guinea-pigs $(180-250 \mathrm{~g}$.) which had fasted overnight, and suspended in a $2 \mathrm{ml}$. bath containing aerated Tyrode solution maintained at $35^{\circ}$. The movements of the longitudinal muscle were recorded with a frontal lever having a magnification of $\times 5$.

Effects of Antagonists. - The effects of the antagonists have been measured in terms of the dose-ratio (Gaddum et al., 1955) by constructing dose-effect curves for the stimulant drugs at the beginning of the experiment, and comparing their subsequent effects in the presence of the antagonist with these curves. The dose-ratio is the ratio of equiactive doses in the presence and absence of the antagonist.

The concentration of the various antagonists was maintained in the bath either by adding fresh doses 
whenever the fluid was changed, or by adding the drug to one of the reservoirs from which the bath could be refilled. The effects of most of the compounds used were complete within 30 to $40 \mathrm{~min}$., but some effects were developing even after $60 \mathrm{~min}$. In such cases, 60 min. was adopted as the standard time at which measurements were made. In order to avoid errors due to the persistence of effects, a separate piece of ileum was used for each experiment.

Histamine and nicotine were used as control drugs. The drugs used were: 5-hydroxytryptamine creatinine sulphate [Upjohn]; histamine acid phosphate, atropine sulphate, and nicotine acid tartrate [British Drug Houses]; morphine hydrochloride [Duncan, Flockhart] ; dibenzyline [Smith, Kline, and French] ; lysergic acid diethylamide (LSD), 2-bromo-lysergic acid diethylamide (BOL-148), and dihydroergotamine methanesulphonate DHErg [Sandoz] ; cocaine hydrochloride [Duncan, Flockhart] ; 3:3-diphenylpropan-3ol-1-diethylamine methiodide (186C47) and methadone hydrochloride [Burroughs Wellcome], and 5-benzyloxygramine (5-BOGram) [Glaxo]. Doses are given in terms of the bases.

\section{RESULTS}

Compounds were tested on the guinea-pig ileum preparation for their effects against 5-HT, histamine, and nicotine by the following method. Suitable doses of 5-HT ( 0.01 to $0.100 \mu \mathrm{g}$.), histamine $(0.005$ to $0.015 \mu \mathrm{g}$.), and nicotine $(0.5$ to $1.5 \mu \mathrm{g}$.) were added in turn at regular intervals, until regular responses were obtained. The doses were then altered and curves constructed by plotting the height of the responses against the doses. The drugs to be tested as antagonists were added in an initial low concentration $(0.001 \mu \mathrm{g}$. $/ \mathrm{ml}$.) and main- tained in the bath for $60 \mathrm{~min}$. During this time 5-HT, histamine, and nicotine were reapplied to the intestine and, if necessary, the doses were increased in order to overcome the inhibition caused by the antagonist. If the effects of the stimulant drugs were unchanged, higher concentrations of the antagonists were tried. The dose-ratios were calculated as described above.

Table I shows the results of some experiments with various drugs which antagonize 5-HT. It is included for comparison with Table II, and to show the effects of morphine and dibenzyline alone in the preliminary treatment of the ileum in the later experiments.

Morphine, in a concentration of $0.01 \mu \mathrm{g} . / \mathrm{ml}$, reduced the response to $5-\mathrm{HT}$ by 50 to $70 \%$, but higher concentrations $(10 \mu \mathrm{g} . / \mathrm{ml}$.) appeared to have no more effect on it (see Kosterlitz and Robinson, 1955).

The depression of the 5-HT response caused by atropine began with a concentration of $0.001 \mu \mathrm{g} . / \mathrm{ml}$., and increased to $40 \%$ at a concentration of $0.01 \mu \mathrm{g} . / \mathrm{ml}$. ; no further depression was produced until the atropine concentration was larger than $1 \mu \mathrm{g} . / \mathrm{ml}$. This confirms the results of Cambridge and Holgate (1955).

The same thing, as already observed by Gaddum and Hameed (1954), occurred with LSD. The depression of the 5-HT contraction began with an LSD concentration of $0.001 \mu \mathrm{g} . / \mathrm{ml}$, increased with a concentration of $0.01 \mu \mathrm{g}$. $/ \mathrm{ml}$., but no further depression was observed with much higher concentrations of LSD $(10 \mu \mathrm{g}$. $/ \mathrm{ml}$.). The effect of LSD is small compared with its effect against

TABLE I

RATIOS OF DOSES OF 5-HYDROXYTRYPTAMINE, HISTAMINE, AND NICOTINE CAUSING EQUAL CONTRACTIONS OF GUINEA-PIG ILEUM IN THE PRESENCE AND ABSENCE OF VARIOUS ANTAGONISTS

\begin{tabular}{|c|c|c|c|c|c|c|c|c|c|c|c|c|c|c|}
\hline \multirow{2}{*}{\multicolumn{2}{|c|}{ Antagonist }} & \multirow{3}{*}{$\frac{\begin{array}{c}\text { Conc. } \\
(\mu \mathrm{g} \cdot / \mathrm{ml} .)\end{array}}{1}$} & \multicolumn{12}{|c|}{ Dose-ratio } \\
\hline & & & \multicolumn{4}{|c|}{ 5-HT } & \multicolumn{4}{|c|}{ Histamine } & \multicolumn{4}{|c|}{ Nicotine } \\
\hline Morphine . . & .. & & $\begin{array}{l}2 \cdot 3 \\
1 \cdot 4 \\
5 \cdot 5 \\
4 \cdot 0\end{array}$ & $\begin{array}{l}1.6 \\
1.5 \\
2.6 \\
5.0\end{array}$ & $\begin{array}{l}8 \cdot 0 \\
4 \cdot 1 \\
4 \cdot 8 \\
2 \cdot 0\end{array}$ & $\begin{array}{l}2 \cdot 6 \\
2 \cdot 5 \\
4 \cdot 0 \\
2.6\end{array}$ & $\begin{array}{l}1.0 \\
1.0 \\
1.0 \\
1.0\end{array}$ & $\begin{array}{l}1 \cdot 0 \\
1 \cdot 1 \\
2 \cdot 0 \\
1 \cdot 2\end{array}$ & $\begin{array}{l}2.5 \\
1.0 \\
1.4 \\
1.2\end{array}$ & $\begin{array}{l}1.0 \\
1.0 \\
1.6 \\
1.5\end{array}$ & $\begin{array}{l}4 \cdot 0 \\
3 \cdot 3 \\
3 \cdot 0\end{array}$ & $\begin{array}{l}1.6 \\
2.1 \\
3.0\end{array}$ & $\begin{array}{l}2 \cdot 6 \\
3 \cdot 7 \\
1.7\end{array}$ & $\begin{array}{l}3 \cdot 0 \\
2 \cdot 2 \\
2 \cdot 0\end{array}$ \\
\hline Atropine $\quad$. & .. & $0 \cdot 1$ & $3 \cdot 3$ & $5 \cdot 0$ & & & $3 \cdot 0$ & $1 \cdot 1$ & & & $1 \cdot 3$ & $1 \cdot 0$ & & \\
\hline $186 C 47$ & .. & 0.07 & $2 \cdot 6$ & 1.4 & $3 \cdot 8$ & & $1 \cdot 2$ & 1.0 & $1 \cdot 2$ & & $2 \cdot 0$ & $2 \cdot 5$ & $3 \cdot 7$ & \\
\hline Cocaine & .. & 10 & $50-100$ & 10 & 20 & 18 & $1 \cdot 2$ & $1 \cdot 0$ & 1.4 & $0 \cdot 8$ & $8 \cdot 2$ & $2 \cdot 5$ & $3 \cdot 0$ & $3 \cdot 3$ \\
\hline Methadone & . & 1 & 50 & 55 & & & $2 \cdot 0$ & $2 \cdot 0$ & & & 10 & 16 & & \\
\hline Dibenzyline & .. & $0 \cdot 1$ & $\begin{array}{l}70 \\
60 \\
32 \\
94 \\
53\end{array}$ & $\begin{array}{l}47 \\
83 \\
30 \\
31\end{array}$ & $\begin{array}{l}60 \\
40 \\
80 \\
44\end{array}$ & $\begin{array}{l}33 \\
66 \\
40 \\
41\end{array}$ & $\begin{array}{r}107 \\
44 \\
150 \\
25\end{array}$ & $\begin{array}{l}40 \\
85 \\
80 \\
43\end{array}$ & $\begin{array}{r}40 \\
60 \\
33 \\
100\end{array}$ & $\begin{array}{r}80 \\
100 \\
210 \\
30\end{array}$ & $\begin{array}{l}2 \cdot 3 \\
1 \cdot 0 \\
2 \cdot 0 \\
2 \cdot 0 \\
1 \cdot 3\end{array}$ & $\begin{array}{l}1 \cdot 5 \\
3 \cdot 0 \\
2 \cdot 1 \\
1.0\end{array}$ & $\begin{array}{l}2 \cdot 2 \\
1 \cdot 2 \\
1 \cdot 5 \\
1 \cdot 2\end{array}$ & $\begin{array}{l}1.5 \\
1.0 \\
1.6 \\
1.0\end{array}$ \\
\hline LSD & . & 0.01 & $6 \cdot 6$ & $8 \cdot 0$ & & & $3 \cdot 0$ & $1 \cdot 1$ & & & $1 \cdot 3$ & $1 \cdot 0$ & & \\
\hline DHErg & .. & $2 \cdot 5$ & 52 & 50 & & & $1 \cdot 2$ & 1.6 & & & $2 \cdot 1$ & $2 \cdot 0$ & & \\
\hline 5-BOGram & . & $0 \cdot 1$ & $4 \cdot 0$ & $6 \cdot 2$ & & & 1.0 & 1.0 & & & $1 \cdot 1$ & 1.0 & & \\
\hline
\end{tabular}


5-HT observed on the rat uterus (Gaddum et al., 1955). Of the drugs shown in Table I, dibenzyline is the only one with much action as an antihistamine.

After these preliminary experiments, morphine and dibenzyline were chosen as the specific antagonists for the two kinds of tryptamine receptor. The receptors which were blocked by morphine have been called the $M$ receptors and those blocked by dibenzyline have been called the $D$ receptors.

When a concentration of $1 \mu \mathrm{g} . / \mathrm{ml}$. of morphine is maintained in the bath, the $M$ receptors appear
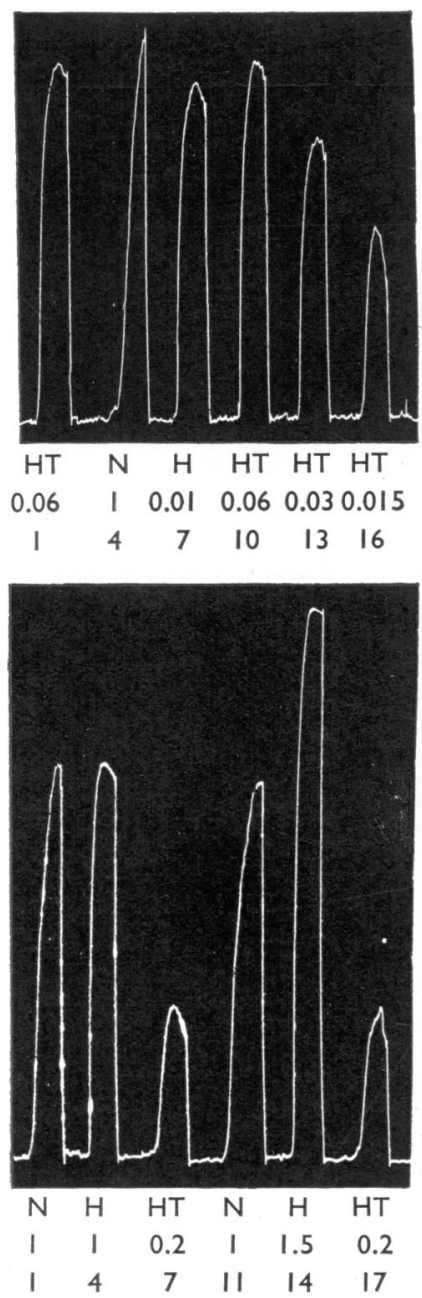
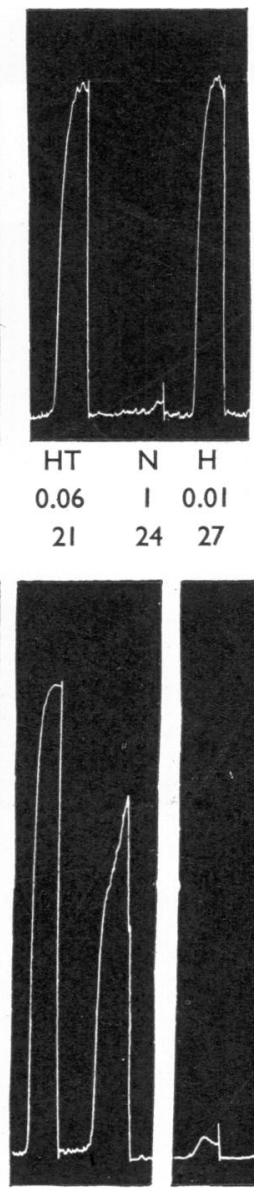

HT HT

$\begin{array}{ll}1.8 & 1.5\end{array}$

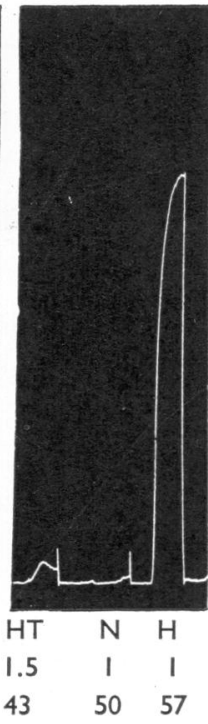

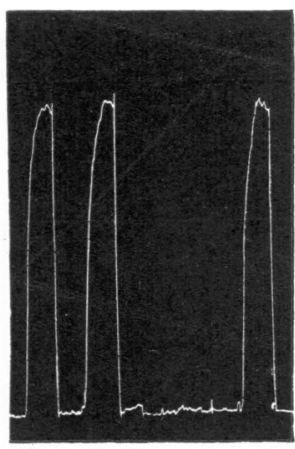

$\begin{array}{llll}\mathrm{H} & \mathrm{HT} & \mathrm{N} & \mathrm{HT}\end{array}$

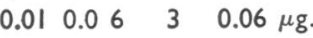

$\begin{array}{llll}55 & 58 \quad 62 \quad 70 \mathrm{~min} .\end{array}$

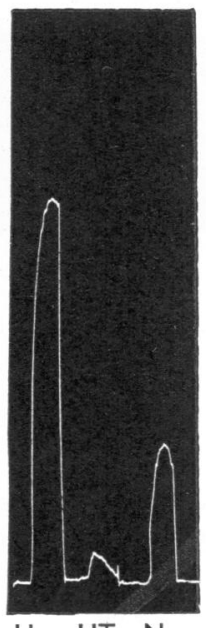

$\mathrm{H} \quad \mathrm{HT} \quad \mathrm{N}$

I.5 $604 \mu \mathrm{g}$.

91 $100110 \mathrm{~min}$.
FIG. 1.-Guinea-pig ileum. Contractions due to 5-HT (HT), nicotine (N) and histamine (H). Doses $\mu \mathrm{g}$. in $2 \mathrm{ml}$. bath. Above with morphine $(1 \mu \mathrm{g} . / \mathrm{ml}$.). Effects on $\mathrm{D}$ receptors unchanged by atropine $(0.1 \mu \mathrm{g} . / \mathrm{ml}$.) from $18 \mathrm{~min}$. onwards. Dose-ratio=1.3. Below after dibenzyline $(0.1 \mu \mathrm{g} . / \mathrm{ml}$. for $30 \mathrm{~min}$.). Effects on $M$ receptors inhibited atropine $(0.1 \mu \mathrm{g} . /$ ml.) from $38 \mathrm{~min}$. onwards. Dose-ratio $>300$ for $5-\mathrm{HT}$. to be more or less completely blocked, and any thought to be $0.1 \mathrm{~g} / \mathrm{ml}$ of dibenzyline for 30 min., the ceptors appear to be more or less completely destroyed and any additional effect is then thought to be on the $M$ receptors. Different pieces of inthe prepared in these two ways thus provide e antagonists on the two types of receptor.

Fig. 1 shows an experiment with atropine type of receptor. In the upper part of this figure effects on the $M$ receptors have been eliminated because these receptors were completely paralysed by morphine throughout the experiment. Atropine had very little effect on the response of 5-HT. A dose of $0.06 \mu \mathrm{g}$. of 5-HT after atropine had about the same effect as $0.045 \mu \mathrm{g}$. of $5-\mathrm{HT}$ before atropine; the dose ratio was therefore estimated as about 1.3. In the lower part of the figure the ileum had been treated with dibenzyline, and the same concentration of atropine had much more effect. It will be seen that $60 \mu \mathrm{g}$. of 5-HT after atropine had less effect than $0.2 \mu \mathrm{g}$. before atropine. The dose-ratio was therefore greater than 300. These results show that atropine had a large effect on the $M$ receptors and little effect on the D receptors. It had little effect on the response to histamine, and it antagonized the effect of nicotine after dibenzyline less than that of 5-HT.

Fig. 2 shows an experiment with 5-benzyloxygramine on each type of receptor. This was the most active of a series of indole compounds tested by Gaddum et al. (1955) 
for antagonism to the action of 5-HT on the rat uterus. This substance had marked antagonism to 5-HT in the presence of morphine, as shown in the upper part of the figure, where $12 \mu \mathrm{g}$. of 5-HT had about as much effect at $97 \mathrm{~min}$. as $0.24 \mu \mathrm{g}$. had at $7 \mathrm{~min}$. The doseratio was therefore estimated as 50. In the presence of dibenzyline (lower records), the effect of this antagonist was comparatively small; in the lower part of the figure it will be seen that $1 \mu \mathrm{g}$. of $5-\mathrm{HT}$ at $110 \mathrm{~min}$. had about the same effect as $0.5 \mu \mathrm{g}$. at $4 \mathrm{~min}$. and 16 min. The dose-ratio was therefore estimated as 2.0 . These results show that 5benzyloxygramine had a large effect on the $D$ receptors and a small effect on the $M$ receptors.

The results of such experiments with various 5-HT antagonists are shown in Table II. Here, when the dose-ratio is 1 it means that the second drug has no effect in addition to that produced by the first drug.

The first five drugs have large effects against 5-HT after treatment of the ileum with dibenzyline and little or no effect in the morphine-treated one. They are thought to act on the $M$ receptors.

The last five drugs have large effects against 5-HT in the presence of morphine and less action in the ileum previously treated with dibenzyline. They are thought to act on the $D$ receptors.

\section{Discussion}

These results indicate that 5-HT causes contractions of the guinea-pig ileum by two different mechanisms, one of which is blocked by dibenzyline (D receptors) and the other of which is blocked by morphine ( $\mathrm{M}$ receptors).
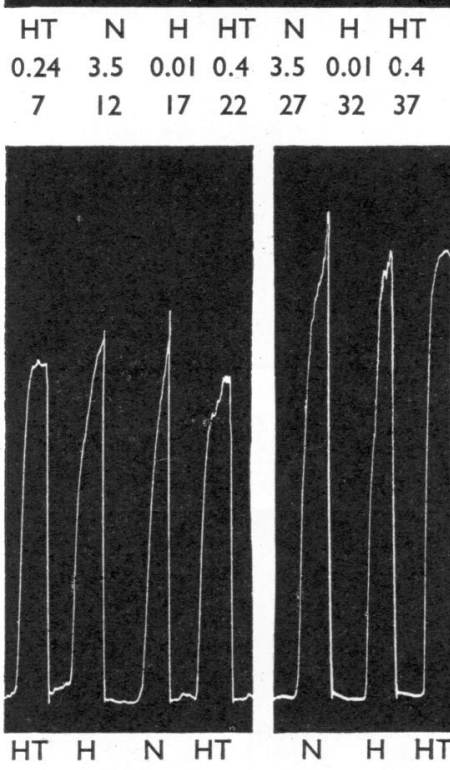

$\begin{array}{llll}0.5 & 0.4 & \text { I.5 } & 0.5\end{array}$

$\begin{array}{llll}4 & 8 & 12 & 16\end{array}$

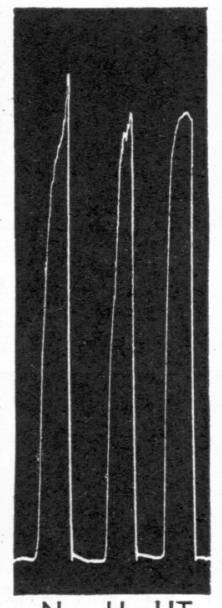

$\mathrm{N} \quad \mathrm{H} \quad \mathrm{HT}$

$\begin{array}{lll}\text { I.8 } & 0.6 & \text { I }\end{array}$

$\begin{array}{lll}40 & 44 & 48\end{array}$
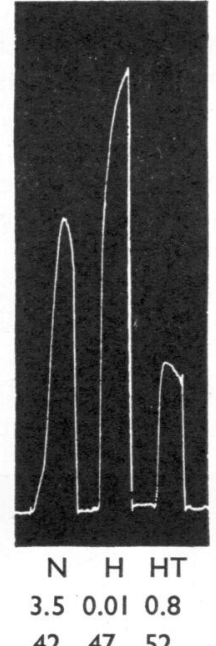

$\begin{array}{lll}42 & 47 \quad 52\end{array}$

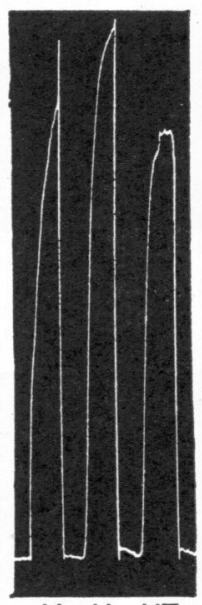

$\begin{array}{ccc}\mathrm{N} & \mathrm{H} & \mathrm{HT} \\ \mathrm{I} .8 & 0.6 & \mathrm{I}\end{array}$

$\begin{array}{lll}53 & 57 \quad 61\end{array}$
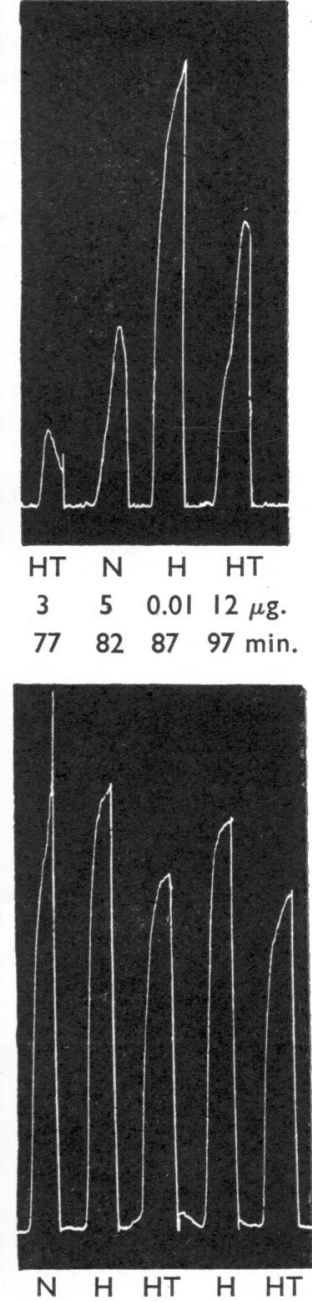

$\begin{array}{llllll}\text { I.8 } & 0.6 & \mathrm{I} & 0.6 & \mathrm{I} & \mu \mathrm{g}\end{array}$

$9095100105110 \mathrm{~min}$.

FIG. 2.-Records as Fig. 1. Above with morphine (1 $\mu \mathrm{g} . / \mathrm{ml}$.). Effects on D receptors inhibited by 5 -benzyloxygramine $(1 \mu \mathrm{g} . / \mathrm{ml}$.) from $38 \mathrm{~min}$. onwards. Dose-ratio $=50$ for 5-HT. Below after dibenzyline $(0.1 \mu \mathrm{g} . / \mathrm{ml}$. for $30 \mathrm{~min}$.). Effects on $M$ receptors almost unchanged by 5 -benzyloxygramine from $50 \mathrm{~min}$. onwards. Dose-ratio $=2$.

The drugs which block the $D$ receptors (dibenzyline, ergot compounds, and 5-benzyloxygramine) are the drugs which antagonize the effects of 5-HT on the rat uterus and the rabbit ear. These effects are thought to be due to an action on smooth muscle and it seems probable that the $\mathrm{D}$ receptors of the guinea-pig ileum are also in smooth muscle.

The drugs which block the $M$ receptors on the other hand probably act on the nerve ganglia or the nerve fibres. Various authors (Rocha e Silva 
TABLE II

RATIOS OF DOSES OF 5-HYDROXYTRYPTAMINE, HISTAMINE, AND NICOTINE CAUSING EQUAL CONTRACTIONS OF GUINEA-PIG ILEUM IN THE PRESENCE AND ABSENCE OF VARIOUS ANTAGONISTS

\begin{tabular}{|c|c|c|c|c|c|c|c|c|c|c|c|c|c|c|}
\hline & \multirow{3}{*}{ Antagonist } & \multirow{3}{*}{$\underset{(\mu \mathrm{g} . / \mathrm{ml} .)}{\text { Conc. }}$} & \multicolumn{12}{|c|}{ Dose-ratio } \\
\hline & & & \multicolumn{6}{|c|}{ After Dibenzyline } & \multicolumn{6}{|c|}{ With Morphine } \\
\hline & & & \multicolumn{2}{|c|}{ 5-HT } & \multicolumn{2}{|c|}{ Histamine } & \multicolumn{2}{|c|}{ Nicotine } & \multicolumn{2}{|c|}{ 5-HT } & \multicolumn{2}{|c|}{ Histamine } & \multicolumn{2}{|c|}{ Nicotine } \\
\hline $\mathbf{M}$ & \begin{tabular}{|ll}
$\begin{array}{l}\text { Morphine } \\
\text { Atropine }\end{array}$ & .. \\
186C47 & .. \\
Cocaine & .. \\
Methadone
\end{tabular} & $\begin{array}{l}1 \\
0.1 \\
0.07 \\
10 \\
1\end{array}$ & $\begin{array}{c}25-35 \\
>400 \\
>16 \\
>320 \\
8 \cdot 0 \\
10-20 \\
200\end{array}$ & $\begin{array}{c}25-50 \\
>300 \\
>300 \\
500 \\
50-100 \\
300\end{array}$ & $\begin{array}{l}1.8 \\
1.5 \\
3.0 \\
1.0 \\
1.2 \\
1.0 \\
2.0\end{array}$ & $\begin{array}{l}1.0 \\
1.0 \\
2.0 \\
1.5 \\
2.0\end{array}$ & $\begin{array}{r}6.6 \\
4-10 \\
6.0 \\
4.0 \\
>4.0 \\
>4.0\end{array}$ & $\begin{array}{r}>10 \\
3.0 \\
3.0 \\
>4.0\end{array}$ & $\begin{array}{l}1.0 \\
1.0 \\
2.0 \\
1.0 \\
4.0\end{array}$ & $\begin{array}{l}1.3 \\
1.4 \\
1.0 \\
4 \cdot 3\end{array}$ & $\begin{array}{l}1.0 \\
1.0 \\
1.0 \\
0.6 \\
1.5\end{array}$ & $\begin{array}{l}1.0 \\
1.4 \\
1.0 \\
1.6\end{array}$ & $\begin{array}{r}>3.0 \\
>3.0 \\
6.0 \\
>3.0 \\
10\end{array}$ & $\begin{array}{c}\mathbf{2} .0 \\
\mathbf{3 . 0} \\
10\end{array}$ \\
\hline D & $\begin{array}{l}\text { Dibenzyline } \\
\text { LSD .. } \\
\text { DHErg. .. } \\
\text { 5-BOGram. } \\
\text { BOL-148 .. }\end{array}$ & $\begin{array}{l}0 \cdot 1 \\
0.01 \\
2 \cdot 5 \\
0 \cdot 1 \\
0.01\end{array}$ & $\begin{array}{l}1.2 \\
1.0 \\
2 \cdot 3 \\
2 \cdot 0 \\
2 \cdot 0\end{array}$ & $\begin{array}{l}6.0 \\
1.5 \\
1.3 \\
1.6\end{array}$ & $\begin{array}{l}1.0 \\
1.0 \\
1.2 \\
1.2 \\
1.0\end{array}$ & $\begin{array}{l}1.0 \\
1.0 \\
1.3 \\
1.0\end{array}$ & $\begin{array}{l}2.0 \\
1.0 \\
1 \cdot 1 \\
1 \cdot 0 \\
1 \cdot 3\end{array}$ & $\begin{array}{l}1.0 \\
1.6 \\
1.0 \\
1.5\end{array}$ & $\begin{array}{c}>400 \\
80-120 \\
100 \\
50 \\
50\end{array}$ & $\begin{array}{c}500 \\
75 \\
125 \\
50 \\
80\end{array}$ & $\begin{array}{r}>400 \\
1.0 \\
1.2 \\
1.2 \\
1.3\end{array}$ & $\begin{array}{r}>1500 \\
1.0 \\
1.0 \\
1.0 \\
1.5\end{array}$ & $\begin{array}{r}2.5 \\
2.6 \\
1.6 \\
1.6 \\
2.6\end{array}$ & $\begin{array}{l}1.4 \\
1.6 \\
1.6 \\
2.0\end{array}$ \\
\hline
\end{tabular}

et al., 1953 ; Robertson, 1953 ; Gaddum and Hameed, 1954 ; Garven, 1956) have come to the conclusion that 5-HT has an action on nervous structures in the guinea-pig ileum. This conclusion has been based on the similarity between the effects of antagonists on the responses to 5-HT and nicotine, and particularly on the fact that the effects of both these drugs are blocked by cocaine.

The results shown in Table II confirm this conclusion. The first four drugs in the Table all showed marked antagonism to 5-HT after dibenzyline, but no definite antagonism to 5-HT in the presence of morphine. Methadone gave similar results, but did show some effect in the presence of morphine. This may mean that methadone has some action on both types of receptor.

These drugs showed definite but feeble antagonism to nicotine, but no definite antagonism to histamine. Since histamine acts on muscle and nicotine on nervous ganglia, this difference confirms the theory that these drugs act on nervous tissues, but they do not necessarily all act in exactly the same place.

Atropine and $186 \mathrm{C} 47$ are known to be specific antagonists of acetylcholine and their effect on the response to 5-HT may be the result of antagonism to the acetylcholine liberated by nerves when these are stimulated by 5-HT. If this is so, it is surprising that their antagonism to the action of nicotine is comparatively feeble. Cocaine is thought to act mainly on the nerve fibres.

The site of action of morphine is uncertain. P. Trendelenburg (1917) found that morphine inhibited both phases of the response of the guineapig ileum to a rise of internal pressure, namely the initial contraction of the longitudinal muscle and the subsequent wave of contraction of the circular muscle. O. Schaumann, Giovannini, and Jochum (1952) showed that the actions of various drugs on these internal reflexes are related to their potency as analgesics, so that the study of the actions of these drugs on the intestine may provide a clue to their central actions. Morphine might produce these effects by acting on the nervous ganglia in the intestine. It has been suggested that its site of action may be in the nerve fibres peripheral to the ganglia (W. Schaumann, 1955), but it must be less peripheral than the site of action of atropine, since the action of morphine, unlike that of atropine, is associated with inhibition of the release of acetylcholine (Paton, 1957 ; W. Schaumann, 1956). These actions of morphine on intestinal reflexes may be related to its antagonism to 5-HT, but the relationship is not necessarily a simple one.

The $\mathrm{M}$ receptors for 5-HT are probably in the nervous tissue of the intestine, but it is not possible to say exactly where they are in this tissue. U. Trendelenburg (1956) has found that small doses of 5-HT, histamine, and certain other substances potentiate the action of acetylcholine on sympathetic ganglia, whether it is injected or liberated by nerves. There is some evidence (U. Trendelenburg, 1957) that the actions of the drugs on ganglia are antagonized by morphine. These results suggest by analogy that 5-HT and morphine both act on autonomic ganglia in the intestine, but there is no direct evidence of this and no proof that they act on the same receptors as one another.

Z. P. Picarelli undertook this work during the tenure of a British Council Scholarship. 


\section{REFERENCES}

Cambridge, G. W., and Holgate, H. J. (1955). Brit. Pharmacol., 10, 326.

Fingl, E., and Gaddum, I. H. (1953). Fed. Proc., 12, 320.

Gaddum, J. H. (1953). J. Physiol., 113, 363.

and Hameed, K. A. (1954). Brit. J. Pharmacol., 9, 240.

Quart. J. exp. Physiol., 40, 49.

Garven, J. D. (1956). J. Pharm., Lond., 8, 256.

Kosterlitz, A. W., and Robinson, J. A. (1955). J. Physiol., 129, 18.
Paton, W. D. M. (1957). Brit. J. Pharmacol., 12, 119.

Robertson, P. A. (1953). J. Physiol., 121, 54.

Rocha e Silva, M., Valle, J. R., and Picarelli, Z.P. (1953). Brit. J. Pharmacol, 8, 378.

Schaumann, O., Giovannini, M., and Jochum, K. (1952). Arch. exp. Path. Pharmak., 215, 460.

Schaumann, W. (1955). Brit. J. Pharmacol., 10, 456. - (1956). Nature, Lond., 178, 1121.

Trendelenburg, P. (1917). Arch. exp. Path. Pharmak., $81,55$.

Trendelenburg, U. (1956). J. Physiol., 132, 529-541. (1957). Brit. J. Pharmacol., 12, 79. 